\title{
Identification and Quantification of Pathogenic Pythium spp. from Soils in Eastern Washington Using Real-Time Polymerase Chain Reaction
}

\author{
K. L. Schroeder, P. A. Okubara, J. T. Tambong, C. A. Lévesque, and T. C. Paulitz
}

First, second, and fifth authors: United States Department of Agriculture-Agricultural Research Service, Root Disease and Biological Control Unit, Washington State University, Pullman 99164; and third and fourth authors: Environmental Health Program-Biodiversity, Agriculture and Agri-Food Canada, 960 Carling Avenue, Ottawa, ON K1A 0C6, Canada.

Accepted for publication 31 January 2006.

\begin{abstract}
Schroeder, K. L., Okubara, P. A., Tambong, J. T., Lévesque, C. A., and Paulitz, T. C. 2006. Identification and quantification of pathogenic Pythium spp. from soils in eastern Washington using real-time polymerase chain reaction. Phytopathology 96:637-647.

Traditional methods of quantifying Pythium spp. rely on the use of selective media and dilution plating. However, high variability is inherent in this type of enumeration and counts may not be representative of the pathogenic population of Pythium spp. Variable regions of the internal transcribed spacer of the rDNA were used to design species-specific primers for detection and quantification of nine Pythium spp. from soils in eastern Washington. Primer pairs were designed for Pythium abappres-

$P$. irregulare group IV, $P$. paroecandrum, $P$. rostratifingens, $P$. sylvaticum, and $P$. ultimum and used with real-time polymerase chain reaction. Standard curves were generated for each of the species using SYBR Green I fluorescent dye for detection of amplification. Seventy-seven isolates of Pythium were screened to confirm specificity of each primer set. DNA was extracted from soil and standard curves were generated for $P$. irregulare group I, $P$. irregulare group IV, and P. ultimum to correlate populations of each species in the soil with quantities of DNA amplified from the same soil. Examination of raw field soils revealed results similar to those observed in previous studies. This new technique for the quantification of Pythium spp. is rapid and accurate, and will be a useful tool in the future study of these pathogenic Pythium spp.
\end{abstract} sorium, $P$. attrantheridium, $P$. heterothallicum, $P$. irregulare group I,
Pythium root rot is a chronic disease of wheat and barley in eastern Washington. More than 10 species of Pythium were implicated in causing root rot and yield loss of wheat and barley in Washington $(8,20,21)$ and numerous species recently were recovered from field soils cropped to wheat (42). These species possess varying degrees of virulence, and the population dynamics of these pathogens is complex. In a recent survey of Pythium spp. throughout eastern Washington, up to six species were recovered from a single soil sample and many different species combinations were identified (42).

Diagnosis of Pythium root rot in the field is challenging due to similarities to symptoms of other seedling diseases. In addition, root symptoms are not readily evident, because obvious lesions do not form on the roots. The primary symptom is reduced seedling vigor, which may be manifested as reduced emergence, plant stunting, reduced first leaf length, and destruction of fine roots and root hairs. However, damage usually is limited to stunting of the plant, and these pathogens rarely kill the plant (13).

Traditional methods of studying the population dynamics of Pythium spp. have involved dilution plating onto a selective medium $(1,11,33)$ and the observation of morphological features to identify individual isolates to species (48). However, these techniques pose some serious constraints to studying this group of pathogens; morphological identification is time consuming and difficult, and some species are asexual or heterothallic, making identification without sexual structures difficult or impossible. The results of dilution plating to determine populations of Pythium

Corresponding author: T. C. Paulitz; E-mail address: paulitz@wsu.edu

DOI: 10.1094/PHYTO-96-0637

This article is in the public domain and not copyrightable. It may be freely reprinted with customary crediting of the source. The American Phytopathological Society, 2006. spp. also may be misleading due to the presence of nonpathogenic species of Pythium or pathogenic species that grow too slowly to be counted. In a collection of Pythium spp. from 80 wheat fields from eastern Washington, Paulitz and Adams (42) found that $30.2 \%$ of the isolates were nonpathogenic P. oligandrum. More recently, molecular approaches were used to identify Pythium spp., including the use of restriction fragment length polymorphisms $(9,10,51)$, hybridization probes $(23,26,27)$, polymerase chain reaction (PCR) (49), PCR enzyme-linked immunosorbent assay (4), and sequencing $(25,29,30,42)$.

Many of these molecular studies with Pythium spp. have focused on the use of the internal transcribed spacer (ITS) sequence from the nuclear ribosomal DNA for species differentiation, although the cytochrome oxidase II gene, encoded by the mitochondria, also has been used for phylogenetic comparisons (29). The ITS regions within Pythium spp. are conserved within a species but variable between species, making differentiation of species using these spacer regions possible $(9,10,25,30)$. The use of ITS sequence data has been a valuable tool along with morphological features to differentiate several new species of Pythium over the past several years $(2,34-41,43)$. Morphological differences are sometimes subtle or overlooked by less-experienced mycologists when working with these pathogens. Recently, sequence data of ITS1 and ITS2 was used to confirm the identity of Pythium spp. collected in eastern Washington (42).

Although previously used molecular techniques were very sensitive and capable of separating many species of Pythium, the techniques were not quantitative or designed for identification directly from a soil or plant sample. A solution to this is real-time PCR for specific amplification and quantification of various species. Real-time PCR quantifies DNA by using a fluorescent dye or probe to detect the product. Monitoring fluorescence during the cycling (52) allows the start of the logarithmic phase of amplification to be identified in order to calculate the initial 
starting concentration of target DNA (6). Specificity can be established by running a melting curve at the end of cycling. Each product formed will have a distinct melting profile based on the length and base composition of the product, providing the means to confirm that a specific amplification occurred. Real-time PCR assays previously were developed for other members of the stramenopila $(7,19,47)$ and several plant-pathogenic fungi $(6,14$, $15,17,24,46)$.

The objectives of this study were to develop primers for the ITS region to use with real-time PCR that would differentiate nine of the most common pathogenic species of Pythium from soils in Washington, and to develop an assay using soil DNA extraction techniques and real-time PCR to identify and quantify Pythium spp. in soil. This was accomplished by identifying speciesspecific primers for nine species of Pythium and using real-time PCR in conjunction with SYBR Green I dye for detection of the product. Standard curves were generated for each species and a soil extraction protocol was developed by modification of a commercially available soil DNA extraction kit.

\section{MATERIALS AND METHODS}

Maintenance of Pythium spp. cultures. Seventy-seven isolates of Pythium representing the nine most commonly isolated pathogenic species found in eastern Washington (42) were used in this study. Working cultures were maintained on potato dextrose agar (PDA) (Difco Laboratories, Sparks, MD) and isolates were stored at $4^{\circ} \mathrm{C}$ on PDA slants. A collection of fungal isolates was used for confirming the specificity of the Pythium primers developed in this study (Table 1). These cultures all were maintained on PDA, with the exception of Phytophthora infestans, which was cultured on corn meal agar.

DNA extraction and sequencing. All isolates of Pythium spp. used for sequencing are listed in Table 1. Each isolate of Pythium was cultured in $15 \mathrm{ml}$ of potato dextrose broth in a petri dish (100 by $15 \mathrm{~mm}$ ) at room temperature until most of the plate was covered with mycelium (5 to 14 days, depending on the isolate). Mycelial mats were washed in distilled water and blotted dry, and
DNA was extracted using the FastDNA Kit (Qbiogene, Carlsbad, CA) along with a FastPrep FP120 cell disrupter (Qbiogene) as described by Paulitz and Adams (42). The ITS regions (ITS1 and ITS2) as well as the 5.8S gene of the rDNA were amplified using the universal eukaryotic primers UN-UP18S42 (5'-CGTAACAAGGTTTCCGTAGGTGAAC-3') and UN-LO28S576B (5'-GTTTCTTTTCCTCCGCTTATTAATATG-3') (5) to produce DNA template for sequencing. Amplification of DNA was performed using a PTC-200 Peltier thermal cycler (MJ Research, Reno, NV) in a $20-\mu \mathrm{l}$ reaction consisting of $16.8 \mu \mathrm{l}$ of nanopure water, $2.5 \mu \mathrm{l}$ of $10 \times$ buffer, $1.9 \mathrm{mM} \mathrm{MgCl}_{2}, 0.2 \mathrm{mM}$ dNTPs, $10 \mathrm{pmol}$ of each primer, $0.2 \mu \mathrm{l}$ of Taq DNA Polymerase (1 unit), and $0.5 \mu \mathrm{l}$ of DNA template. The Taq Polymerase, $10 \times$ buffer, and $\mathrm{MgCl}_{2}$ were obtained from Promega Corporation (Madison, WI). The following program was used to amplify the DNA: $3 \mathrm{~min}$ at $94^{\circ} \mathrm{C}$ ( 1 cycle); $45 \mathrm{~s}$ at $92^{\circ} \mathrm{C}, 45 \mathrm{~s}$ at $60^{\circ} \mathrm{C}$, and $60 \mathrm{~s}$ at $72^{\circ} \mathrm{C}$ (30 cycles); and $10 \mathrm{~min}$ at $72^{\circ} \mathrm{C}(1$ cycle $)$.

Prior to sequencing, remaining dNTPs and primers were removed from the PCR product by treating $5 \mu \mathrm{l}$ of the product with $2 \mu \mathrm{l}$ of ExoSAP-IT (USB Corporation, Cleveland, OH). The mixture was incubated at $37^{\circ} \mathrm{C}$ for $30 \mathrm{~min}$ and the enzymes were inactivated by incubation at $80^{\circ} \mathrm{C}$ for $15 \mathrm{~min}$. Sequencing reactions were completed for both strands of the ITS regions and the 5.8S rDNA using the universal eukaryotic forward and reverse primers listed above, along with two internal primers located in the 5.8S gene. OOM-LO5.8S47B (5'-CGCATTACGTATCGCAGTTCGCAG- $\left.3^{\prime}\right)$ is a reverse primer located at the $5^{\prime}$ end of the 5.8S and amplified ITS1, whereas OOM-UP5.8S01 (5'-CAACTTTCAGCAGTGGATGTCT-3') is a forward primer located at the $3^{\prime}$ end of the 5.8S gene to amplify ITS2 (32). The sequencing reactions were set up using a $10-\mu$ l total volume that consisted of $4 \mu \mathrm{l}$ of ABI PRISM BigDye Terminator Cycle Sequencing Ready Reaction Kit (Applied Biosystems, Foster City, CA), 4 pmol of primer, and $5 \mu \mathrm{l}$ of ExoSAP-IT product. The following program was used to amplify the DNA: 2 min at $94^{\circ} \mathrm{C}$ ( 1 cycle); and 2 min at $94^{\circ} \mathrm{C}, 1 \mathrm{~min}$ at $50^{\circ} \mathrm{C}$, and $1.5 \mathrm{~min}$ at $60^{\circ} \mathrm{C}$ ( 24 cycles). Reactions were run through a Sephadex G-50 column using $1 \mathrm{ml}$ of a Sephadex suspension in a mini-column. The columns were pre-

TABLE 1. Isolates of Pythium spp. and other fungi used in this study

\begin{tabular}{|c|c|c|c|c|c|}
\hline Species & Isolate $^{\mathrm{a}}$ & Site of isolation ${ }^{b}$ & Origin (county, city) ${ }^{\mathrm{c}}$ & GenBank accession no. & Source ${ }^{d}$ \\
\hline Pythium abappressorium & 020162 & Wheat & Adams, Ritzville & DQ091294 & T. Paulitz \\
\hline P. attrantheridium & 020169 & Barley & Lincoln, Davenport & DQ091296 & T. Paulitz \\
\hline P. heterothallicum & 090014 & Barley & Kootenai, Rockford & DQ091298 & T. Paulitz \\
\hline$P$. irregulare group I & 0900101 & Spring wheat & Benewah, Tensed & DQ091295 & T. Paulitz \\
\hline P. irregulare group IV & 020155 & Spring wheat & Spokane, Latah & DQ091299 & T. Paulitz \\
\hline P. paroecandrum & 090031 & Lentil & Whitman, Palouse & DQ091297 & T. Paulitz \\
\hline P. rostratifingens & 020172 & Spring wheat & Columbia, Dayton & DQ091300 & T. Paulitz \\
\hline P. sylvaticum & 0900115 & Lentil & Whitman, Pullman & DQ091301 & T. Paulitz \\
\hline P. ultimum & 030141 & - & Kootenai, Rockford & DQ091302 & T. Paulitz \\
\hline Aphanomyces euteiches & Ae02A9 & Pea & Eastern Washington & - & N. Grünwald \\
\hline Bipolaris sorokiniana & BS15e-99 & Winter wheat & Eastern Washington & - & K. Schroeder \\
\hline Fusarium culmorum & F070366 & Wheat & Whitman, Pullman & - & T. Paulitz \\
\hline F. pseudograminearum & $006-13$ & Winter wheat & Wasco, Unknown & - & R. Smiley \\
\hline Gaeumannomyces graminis var. tritici & R3-111a-1 & Wheat & Grant, Moses Lake & - & D. Weller \\
\hline Mortierella hyalina & $\mathrm{P} 2 \mathrm{c} 3$ & Winter wheat & Whitman, Pullman & - & K. Schroeder \\
\hline Phytophthora infestans & W03GE & Potato & Grant, George & - & D. Johnson \\
\hline Rhizoctonia oryzae & $\mathrm{Rh} 070332$ & Wheat & Adams, Lind & - & T. Paulitz \\
\hline Rhizoctonia solani & Rh100279 & Chickpea & Walla Walla, Walla Walla & - & T. Paulitz \\
\hline Trichoderma polysporum & P1cc9 & Winter wheat & Whitman, Pullman & - & K. Schroeder \\
\hline T. viride & W3b4 & Winter wheat & Whitman, Pullman & - & K. Schroeder \\
\hline
\end{tabular}

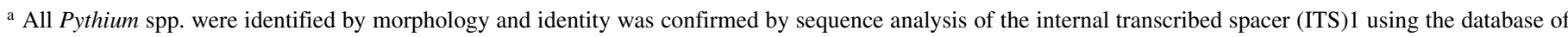
C. A. Lévesque, Agriculture and Agri-Food Canada, Ottawa, Canada.

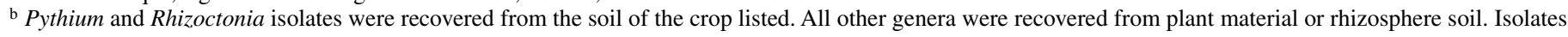
with a dash (-) were isolated from agricultural fields that were either fallow or harvested prior to sampling.

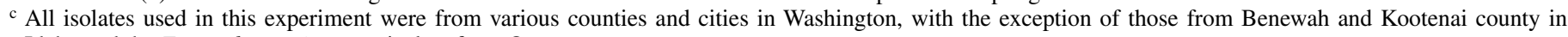
Idaho and the F. pseudograminearum isolate from Oregon.

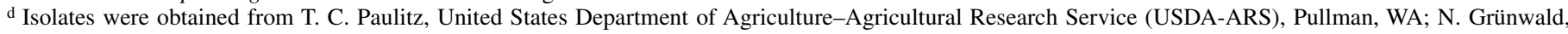
USDA, Corvallis, OR; K. L. Schroeder, Washington State University, Pullman; R. W. Smiley, Oregon State University, Pendleton; D. M. Weller, USDA-ARS, Pullman, WA; and D. A. Johnson, Washington State University, Pullman. 
spun at $750 \times g$ for $2 \mathrm{~min}$, and then the sequencing reaction was brought up to $20 \mu \mathrm{l}$ by adding nanopure water, placed onto the top of the spin column, and spun for an additional $2.5 \mathrm{~min}$ at $750 \times \mathrm{g}$. The sequence reactions were run on an Applied Biosystems sequencer (model 377; Applied Biosystems). At least two complete sequences were obtained for each region of the ITS1, 5.8S, and ITS2 sequence. The resulting sequences were assembled using SeqMan II (version 5.00; DNASTAR, Madison, WI), aligned using ClustalW version 1.8, and box shaded using GeneDoc (version 2.6.002) (Pittsburgh Supercomputing Center, Pittsburgh, PA).

Primer design and preliminary screen for specificity. Primer pairs were selected for $P$. abappressorium Paulitz \& Mazzola, $P$. attrantheridium Allain-Boulé \& Lévesque, $P$. heterothallicum W. A. Campb. \& F. F. Hendrix, P. irregulare Buisman (groups I and IV), $P$. paroecandrum Drechsler, $P$. rostratifingens de Cock and Lévesque, $P$. sylvaticum W. A. Campb. \& F. F. Hendrix, and P. ultimum Trow using the variable regions of ITS1 and ITS2. Each primer was designed with an annealing temperature of $\approx 68$ to $70^{\circ} \mathrm{C}$ and analyzed for dimer or hairpin loop structures using GeneRunner (version 3.05; Hastings Software, Inc., Hudson, NY). A primer sequence database was generated in PrimerSelect (version 5.00; DNASTAR) and a preliminary screen was conducted using each Pythium sequence and examining for cross specificity. Primers pairs that would generate a PCR product of 100 to $400 \mathrm{bp}$ were selected for further study and initially screened for dimer formation using Oligo (version 6.65; Molecular Biology Insights, Cascade, CO). Primer pairs were optimized for temperature and $\mathrm{MgCl}_{2}$ concentration using an iCycler iQ gradient thermal cycler (Bio-Rad, Hercules, CA). Each 10- $\mu$ PCR reaction consisted of $9.8 \mu \mathrm{l}$ of nanopure water, $1.5 \mu \mathrm{l}$ of $10 \times$ buffer, 1.5 to $4.0 \mathrm{mM} \mathrm{MgCl}, 0.2 \mathrm{mM}$ dNTPs, 6 pmol of each primer, $0.15 \mu \mathrm{l}$ (0.75 units) of Taq DNA Polymerase, and $1 \mu \mathrm{l}$ of DNA template. The following program was used to amplify the DNA: 4 min at $94^{\circ} \mathrm{C}(1$ cycle $) ; 45 \mathrm{~s}$ at $92^{\circ} \mathrm{C}, 45 \mathrm{~s}$ at 50 to $70^{\circ} \mathrm{C}$, and $60 \mathrm{~s}$ at $72^{\circ} \mathrm{C}$ (30 cycles); and $7 \mathrm{~min}$ at $72^{\circ} \mathrm{C}$. PCR products were separated on a $2 \%$ agarose gel stained with ethidium bromide.

An isolate of Pythium representing each of the nine species was selected for a preliminary test for specificity (Table 1). Those primers that amplified only the species for which the primers were designed were selected for further screening of the entire collection of 77 isolates. Primer sets that resulted in any nonspecific amplification were discarded.

Generation of standard curves. A standard curve was generated individually for each primer set, using the nine Pythium spp. isolates (Table 1) as template. The quantity of DNA for each isolate was determined in a $200-\mu \mathrm{l}$ volume in 96 -well plates using Hoechst 33258 dye and a Safire fluorescence plate reader (TECAN Research, Triangle Park, NC). The DNA concentrations for each isolate were standardized to a final concentration of $\approx 5 \mathrm{ng} / \mu \mathrm{l}$. A set of dilutions was completed with 10 -fold reductions in DNA concentrations from $5 \mathrm{ng} / \mu \mathrm{l}$ to $5 \mathrm{fg} / \mu \mathrm{l}$. A $20-\mu \mathrm{l} \mathrm{PCR}$ was set up in borosilicate glass capillaries in triplicate for each DNA concentration. The mix consisted of $12.8 \mu \mathrm{l}$ of nanopure water, $2.0 \mu \mathrm{l}$ of LightCycler FastStart DNA Master SYBR Green I (Roche Applied Science, Indianapolis, IN), $4 \mathrm{mM} \mathrm{MgCl}_{2}, 8 \mathrm{pmol}$ of each primer, and $2 \mu \mathrm{l}$ of template DNA. Real-time PCR was conducted on a Roche LightCycler (Roche Applied Science) using the program $10 \mathrm{~min}$ at $95^{\circ} \mathrm{C}(1$ cycle $)$; and $10 \mathrm{~s}$ at $95^{\circ} \mathrm{C}, 5 \mathrm{~s}$ at $70^{\circ} \mathrm{C}$, and $10 \mathrm{~s}$ at $72^{\circ} \mathrm{C}(50$ cycles $)$. A melting curve of the product was generated by ramping the temperature to $95^{\circ} \mathrm{C}$ for $0 \mathrm{~s}$, back to $70^{\circ} \mathrm{C}$ for $15 \mathrm{~s}$, and then incremental increases of $0.1^{\circ} \mathrm{C} / \mathrm{s}$ up to $95^{\circ} \mathrm{C}$ with continuous measurement of fluorescence. The resulting data were analyzed with the LightCycler Software version 3, using the arithmetic baseline adjustment and second derivative maximum analysis. The data was used to generate standard curves and the standard deviation of each DNA concen- tration was calculated and plotted to estimate variability across a range of DNA quantities.

Evaluation of primer specificity using real-time PCR and in silico analysis. Each primer set was screened for specificity using the collection of 77 Pythium isolates and other genera (Table 1) by amplification using real-time PCR and the protocol listed above. The DNA concentrations for each isolate were standardized to 1.0 to $1.5 \mathrm{ng} / \mu \mathrm{l}$, and $2 \mu \mathrm{l}$ of DNA was included in each reaction for a final concentration of 2 to $3 \mathrm{ng}$ per reaction. For each primer set, the appropriate positive control was included at $1 \mathrm{ng}$ per reaction, and water was used as the negative control.

Primer specificity also was evaluated by calculating the primertarget duplex stabilities ( $\Delta \mathrm{G}$ values) using the nearest neighbor model of PrimerSelect 5.00 at default scoring settings of $50 \mathrm{mM}$ salt, $25^{\circ} \mathrm{C}$, and $0.76 \mathrm{kcal} \mathrm{mol}^{-1} \mathrm{bp}^{-1}$ average stability cut-off. Duplex stability values were obtained for the specific target sequences used to design the primers and 18 additional Pythium ITS sequences from GenBank that represented all nine target Pythium spp. To evaluate the potential of each primer to form hybrids with ITS sequences from nontarget Pythium spp., hybrid stability values were obtained in silico using 64 GenBank ITS sequences representing 28 nontarget Pythium spp. These species included $P$. aphanidermatum, $P$. carolinianum, $P$. cylindrosporum, $P$. cystogenes, $P$. debaryanum, $P$. echinulatum, $P$. grandisporangium, $P$. hydnosporum, $P$. insidiosum, $P$. intermedium, $P$. kunmingense, $P$. litoralis, $P$. macrosporum, $P$. mamillatum, $P$. mastophorum, P. middletonii, $P$. minus, $P$. monospermum, $P$. myriotylum, $P$. oligandrum, $P$. pachycaule, $P$. pleroticum, $P$. rostratum, $P$. spinosum, $P$. splendens, $P$. torulosum, $P$. ultimum var. sporangiiferum, $P$. undulatum, and $P$. violae.

Real-time PCR amplification from artificially infested and natural soils. Soils were artificially infested with Pythium spp. to evaluate the ability to extract and subsequently amplify Pythium DNA from soil. Ground oatmeal (Old Fashioned Style Quaker Oats; The Quaker Oats Company, Chicago) was added at $1 \%$ (wt/wt) to a Ritzville coarse silty loam soil from Lind, WA that was air dried and sieved through a $2-\mathrm{mm}$ sieve. Water was added to the soil at $10 \%(\mathrm{wt} / \mathrm{wt})$ and $70 \mathrm{~g}$ of the soil mixture was placed into 140-ml-volume jars with "B-cap" style Magenta lids. The soil was autoclaved on two consecutive days for $45 \mathrm{~min}$ each. One day prior to infesting the soils, $10 \mathrm{ml}$ of water was added to each jar and allowed to infiltrate overnight. Three agar plugs $(\approx 4 \mathrm{~mm}$ in diameter) from a 4- to 5-day culture were placed into each jar, and jars were shaken vigorously to mix the inoculum and disperse the moistened soil throughout the jar. Jars were incubated for 3 to 6 months prior to use. Populations of Pythium spp. within each jar were determined by serial dilution of $1 \mathrm{~g}$ of infested soil in water and plating onto Pythium selective medium (PSM) (33), using 2\% water agar rather than cornmeal agar $(2 \%$ water agar with pentachloronitrobenzene at $100 \mu \mathrm{g} / \mathrm{ml}$, pimaricin at $0.25 \mu \mathrm{l} / \mathrm{ml}$, rose bengal at $10 \mu \mathrm{g} / \mathrm{ml}$, and rifampicin at $50 \mu \mathrm{g} / \mathrm{ml}$ ).

A standard curve was generated to relate the population of Pythium spp. in soil as determined by dilution plating with the quantity of DNA amplified by real-time PCR. P. irregulare group I isolates 0900101 (Tensed, ID), 110305 (Garfield, WA), and 110306 (Garfield, WA); P. irregulare group IV isolates 020117 (Palouse, WA), 020147 (Palouse, WA), and 020155 (Latah, WA); and P. ultimum isolates 030141 (Rockford, WA), 10118 (Dusty, WA), and 10145 (Davenport, WA) were used to generate standard curves. Pythium-infested soils were diluted into a pasteurized Thatuna silt loam from the Spillman Agronomy Farm (Pullman, WA) to obtain final concentrations of $0,10,50,100,500$, and 1,000 propagules per gram (ppg). Pasteurization was accomplished using a steam cart (Seibring Mfg., George, IA) at $60^{\circ} \mathrm{C}$ for $30 \mathrm{~min}$. Total DNA was extracted from the soil samples using the UltraClean Soil DNA Kit (MO BIO Laboratories, Solana Beach, CA). From each soil dilution, three separate 500-mg samples of soil were processed with the DNA extraction kit using 
the alternative protocol for maximum yields. The cell disruption step was modified, using the FastPrep FP120 at a speed of 5.0 for $45 \mathrm{~s}$ in place of vortexing for $10 \mathrm{~min}$. The final volume from the DNA extraction procedure was $50 \mu \mathrm{l}$. Real-time PCR reactions were conducted in a total volume of $20 \mu \mathrm{l}$, using $2 \mu \mathrm{l}$ of undiluted DNA from the soil extractions. The reaction mix and PCR program were the same as described above. The resulting DNA quantification from real-time PCR was multiplied by 50 to obtain the concentration of DNA per gram of soil and plotted against the number of propagules per gram of soil as determined by dilution plating.

DNA extraction and real-time PCR amplification also was conducted using $500 \mathrm{mg}$ of samples removed directly from the field. Soils were collected from five locations on 16 September 2004 following periodic rainfall occurring from 12 to 15 September 2004. These locations included a fallow field and a field cropped to barley north of Garfield, WA; a fallow field and a field cropped to winter wheat at the Cunningham Agronomy Farm northeast of Pullman, WA; and a field cropped to spring wheat at the Agricultural Research Service (ARS) Palouse Conservation Farm north of Pullman, WA. DNA extractions and real-time PCR were repeated after air drying a portion of each sample for 3 days. Total DNA was extracted from wet and dry soils using the protocol described above and real-time PCR was conducted as described previously. For this experiment, each of the nine primer pairs was tested on each soil sample. The populations estimated by real-time PCR were compared with results using traditional techniques of plating onto selective media. The total population of Pythium spp. in the soil was estimated by serial dilution of $1 \mathrm{~g}$ of soil in water and dilution plating onto PSM.

To rule out the presence of PCR inhibitors in the soil, purified DNA from $P$. irregulare group I, $P$. irregulare group IV, and $P$. ultimum was used to spike soil extracts in order to compare efficiencies. Extracts were made by using the UltraClean Soil DNA Kit as described above. Soils used in this assay were obtained from the Cunningham Farm, Garfield and the ARS Palouse Conservation Farm. A dilution series was made to test DNA concentrations at 10 -fold increments from 0.01 to $100 \mathrm{pg}$. Realtime PCR was conducted as described previously and data plotted to obtain efficiencies. Mean comparisons of the efficiencies were conducted using Fisher's least significant difference (LSD) at $P=$ 0.05. Analysis was performed using SAS (version 8.2; SAS Institute Inc., Cary, NC).

Confirmation of species identified in natural field soils. The identity of species detected and identified by real-time PCR were confirmed using traditional techniques for isolation and microscopic identification, and soil extracts also were processed using macroarray analysis (45). To determine the relative composition of Pythium spp. by traditional microscopy, $10 \mathrm{~g}$ of soil from each sample were placed into a petri dish and flooded with $25 \mathrm{ml}$ of sterile distilled water. Fresh grass blades were placed onto the surface of the water and incubated for $24 \mathrm{~h}$ at room temperature $\left(\approx 21^{\circ} \mathrm{C}\right)$. The grass blades were transferred to PSM to select for Pythium spp., subcultured onto $2 \%$ water agar to obtain single isolates, and transferred to PDA for maintenance of the isolate. Agar plugs $(\approx 4 \mathrm{~mm}$ in diameter) were transferred to a petri dish with $\approx 25 \mathrm{ml}$ of sterilized pond water containing dried, sterilized grass blades. After 4 to 6 days of incubation at room temperature, the grass blades were examined for the presence of sporangia and oospores to identify isolates to species, using the taxonomic keys of Van der Plaats-Niterink (47).

A separate soil sample was collected from all three field locations in October 2005 for macroarray analysis. DNA was extracted from each soil and detection of Pythium spp. by DNA macroarray was accomplished using the protocols for PCR amplification, digoxigenin-labeling, and detection as described by Tambong et al. (45). Universal ITS primers for eukaryotes, UNUP18S42 (forward, 5'-CGTAACAAGGTTTCCGTAGGTGAAC-
3') and OOM-LO28S345H (reverse, 5'-ACTTGTTCGCTATCGGTCTCGCA-3'), were used to produce labeled PCR amplicons. Hybridizations were done overnight and digoxigenin detected by chemiluminescence according to the protocol from the manufacturer by using anti-Digoxigenin alkaline phosphatase conjugate and the chemiluminescent substrate CDP-Star (Roche Diagnostics $\mathrm{GmbH}$, Mannheim, Germany). Hybridizations were done twice to confirm results and specificity of the oligonucleotides.

\section{RESULTS}

DNA sequencing and primer design. A complete sequence of the ITS1, 5.8S, and ITS2 were obtained for each Pythium sp. listed in Table 1. Upon examining variable regions of the sequence, a series of forward and reverse primers were selected manually, using GeneRunner to eliminate primers with obvious dimer or hairpin loop problems. Between 2 and 14 primer sets initially were selected for each species of Pythium. A range of $\mathrm{MgCl}_{2}$ concentrations was tested for each primer set; however, all primers functioned equally well at all concentrations tested (1.5 to $4.0 \mathrm{mM}$ ). Using a temperature gradient from 50 to $70^{\circ} \mathrm{C}$, a number of primers were found to form substantial amounts of dimer at lower temperatures. Primer sets that consistently amplified at an annealing temperature of $70^{\circ} \mathrm{C}$ were used for further testing. A preliminary screen for specificity was conducted using traditional and real-time PCR and a species-specific primer pair was identified for each Pythium sp. that formed minimal or no dimers and resulted in no nonspecific amplification (Table 2). The primer pairs selected produce a product size of 277 to $414 \mathrm{bp}$ and each set produced a characteristic melting peak.

Standard curves for real-time PCR. A single primer pair for each Pythium sp. was selected and standard curves were generated for each primer set using a range of DNA from $10 \mathrm{fg}$ to $10 \mathrm{ng}$. Standard curves were obtained with very reproducible amplification and very high correlation values for each primer pair (Fig. 1). The slopes were very similar for each species, resulting in amplification efficiencies ranging from $80 \%$ for $P$. paroecandrum to $92 \%$ for $P$. attrantheridium. The $y$ intercept $(1 \mathrm{pg}$ of DNA) for each species ranged from 24.74 cycles for $P$. ultimum to 28.41 for $P$. paroecandrum. The standard deviation of the $\log$ DNA concentration, calculated in generating the standard curves, varied from 0.004 to 0.096 (average $=0.033$ ) at DNA concentrations of 0.1 to $10,000 \mathrm{pg}$ (Fig. 2). However, at DNA concentrations $<0.1 \mathrm{pg}$ of DNA (cycle threshold $\left[\mathrm{C}_{\mathrm{t}}\right]$ value $\approx 32$ to 36 ), the standard deviation ranged from 0.026 to 0.470 (average $=$ 0.147).

Evaluation of primer specificity using real-time PCR and in silico analysis. Each set of primers was examined for specificity using the collection of 77 isolates of Pythium spp., with 2 to 14 isolates representing each of the species of Pythium. Due to the capacity of the LightCycler (32 samples), these isolates were divided randomly into three groups, with three separate runs necessary to test each primer pair. Every combination of Pythium isolate-primer set was tested. In every case, only those species for which the primer set was designed were amplified using real-time PCR (Table 3). A positive amplification was characterized by a $C_{t}$ value in the range of 11.5 to 16.6 with a characteristic melting profile, and a negative amplification was characterized by a $\mathrm{C}_{t}$ value in excess of 29.0 as well as a melting profile indicative of nonspecific amplification. No nonspecific amplification was detected with any of the primer sets. Additional genera of fungi and oomycetes listed in Table 1 that either are found in the soils of agricultural production areas in eastern Washington or with similar phylogenetic relation to Pythium spp. were screened with each set of primers. In every case, the primers did not amplify target DNA from the nonspecific genera and, when nonspecific amplification did occur, the measured DNA concentration was below $1 \mathrm{fg}$ and atypical melting peaks were generated. 
The stability ( $\Delta \mathrm{G}$ values) of primer-target duplexes ranged from $-47.3 \mathrm{kcal} \mathrm{mol}^{-1}$ for the $P$. rostratifingens primer ROS4F to $-39.8 \mathrm{kcal} \mathrm{mol}^{-1}$ for the $P$. heterothallicum primer HET4F, with an average of $-43.3 \mathrm{kcal} \mathrm{mol}^{-1}$ for all species-specific primers. Because these values were obtained for strains from Japan, China, France, and Australia, we expect that our primers will be useful for a wide geographical range of Pythium spp. In contrast, $\Delta \mathrm{G}$ values for most of the nontarget (nonspecific Pythium spp.) hybrids were either below the default stability cut-off or greater than $-20 \mathrm{kcal} \mathrm{mol}^{-1}$. These relatively high values are not correlated with significant or specific amplification under the conditions of our real-time PCR. Primers ABA1bF, IRR3cF, PAR2F or PAR3R (but not both), and SYL1F displayed hybrid stability values of less than $-32 \mathrm{kcal} \mathrm{mol}^{-1}$ when complexed in silico with one or more of the species $P$. cylindrosporum, $P$. debaryanum, $P$. insidiosum, $P$. intermedium, $P$. macrosporum, $P$. mamillatum, $P$. spinosum, $P$. torulosum, $P$. ultimum var. sporangiiferum, and $P$. violae. Primer ATT2R also formed a stable hybrid with the $P$. intermedium ITS sequence $(\Delta \mathrm{G}=-37.9)$. Because only one primer of a pair formed a hybrid of $-32 \mathrm{kcal} \mathrm{mol}^{-1}$ or less, significant amplification of nontarget DNA is not expected. However, amplification of $P$. sylvaticum DNA with PAR3R (and SYL1F) precludes multiplexing assays for $P$. sylvaticum and $P$. paroecandrum.

Real-time PCR amplification from artificially infested and natural soils. Pythium DNA was extracted successfully from artificially infested soil samples. In addition, the modification of the extraction protocol using the FastPrep FP120 was found to be an effective means of disruption. Soils were serially diluted to obtain populations densities that were representative of soils in eastern Washington and DNA was extracted from each dilution. Efficiency of DNA extraction and amplification with real-time PCR using primers specific for each species resulted in a proportional increase in DNA quantification across the entire range of Pythium populations examined, with correlations in excess of 0.909 for each species examined (Fig. 3). Using populations of Pythium spp. from $\approx 10$ to $1,000 \mathrm{ppg}, \mathrm{C}_{\mathrm{t}}$ values ranged from 31.29 to 24.41 for $P$. irregulare group I, 32.68 to 23.99 for $P$. irregulare group IV, and 30.95 to 22.50 for P. ultimum.
Soil samples were collected from five locations in Whitman County in eastern Washington to test the ability of the real-time PCR procedure to detect Pythium spp. directly from natural field soils. Portions of each soil sample were air dried, so that both wet and dry samples were examined. Similar quantities of DNA were amplified from both wet and dry soils, with at least three different species usually amplified from each soil, although only two species of Pythium were amplified from the fallow soil collected in Garfield, WA (Table 4). Six species of Pythium were detected from the soil cropped to spring barley at Garfield, and P. irregulare group IV likely also was present, but quantification was not possible. The quantity of Pythium spp. DNA extracted from each soil followed the same trend as with serial dilution and plating soils onto selective media to quantify the population of Pythium spp. The lowest amplification with real-time PCR and quantification on selective media was associated with fallow soil at Garfield. The Cunningham Agronomy Farm samples and soil from the ARS Palouse Conservation Farm were intermediate in population and PCR amplification, and the spring barley cropped soil from Garfield was the highest, with the exception of the moist soil from the ARS Palouse Conservation Farm.

Soil extracts were spiked with known amounts of Pythium spp. DNA, using a range of 0.01 to $100 \mathrm{pg}$. Similar efficiencies were calculated for DNA amplification from extracts of all three soils (Table 5). Although slight variations in efficiency were observed, the means did not significantly differ from each other or the water control using Fisher's LSD at $P=0.05$.

Confirmation of species identified in natural field soils. Sixty-four isolates of Pythium spp. were isolated from soil samples by baiting using fresh grass blades, with the majority of the isolates being recovered from soils that were cropped in 2004 versus fallowed (Table 6). P. rostratifingens was the most commonly recovered species, representing $48 \%$ of the isolates. $P$. irregulare group IV represented $19 \%$ of the isolates and $P$. abappressorium represented $13 \%$. Four isolates of $P$. heterothallicum and one isolate of $P$. irregulare were recovered as well as five isolates of $P$. pachycaule and three unidentified isolates. However, two species of Pythium amplified by real-time PCR

TABLE 2. Species-specific primers for pathogenic Pythium spp.

\begin{tabular}{|c|c|c|c|c|}
\hline Species & Primer & Sequence $\left(5^{\prime} \rightarrow 3^{\prime}\right)$ & $\begin{array}{l}\text { Product size } \\
\quad(\mathrm{bp})\end{array}$ & $\begin{array}{l}\text { Melting peak } \\
\left({ }^{\circ} \mathrm{C}\right)^{\mathrm{a}}\end{array}$ \\
\hline Pythium abappressorium & $\begin{array}{l}\text { ABA1bF } \\
\text { ABA1R }\end{array}$ & $\begin{array}{l}\text { GTTGTTGTGCGTCTGCGGATTTG } \\
\text { TGCATAAACGAATATACCAACCGC }\end{array}$ & 397 & 84.8 \\
\hline P. attrantheridium & $\begin{array}{l}\text { ATT3F } \\
\text { ATT2R }\end{array}$ & $\begin{array}{l}\text { GTTTGTGGTCATTTTGGCTGCG } \\
\text { CGCTACTAACAAAGCAGATCCCAG }\end{array}$ & 277 & 88.3 \\
\hline P. heterothallicum & $\begin{array}{l}\text { HET4F } \\
\text { HET2R }\end{array}$ & $\begin{array}{l}\text { GTGAAGTGTCTCGCGCACTTG } \\
\text { GTAACCATGCATGCTGCACCA }\end{array}$ & 304 & 86.6 \\
\hline P. irregulare group I & $\begin{array}{l}\text { IRR3cF } \\
\text { IRR3R }\end{array}$ & $\begin{array}{l}\text { GCTGTGGTTGGTGTTTGTTGTTTGC } \\
\text { CTGTACAATTGCACACACACAAGTATG }\end{array}$ & 344 & 88.9 \\
\hline P. irregulare group IV & $\begin{array}{l}\text { IIV7F } \\
\text { ABA1R }\end{array}$ & $\begin{array}{l}\text { GTATCGTCTTGGCGGAGTGG } \\
\text { TGCATAAACGAATATACCAACCGC }\end{array}$ & 370 & 85.5 \\
\hline P. paroecandrum & $\begin{array}{l}\text { PAR2F } \\
\text { PAR3R }\end{array}$ & $\begin{array}{l}\text { TGGTTGGCGTTCGTTGTTTG } \\
\text { GGATCAACCCGGAGTACACTAATT }\end{array}$ & 398 & 89.1 \\
\hline P. sylvaticum & $\begin{array}{l}\text { SYL1F } \\
\text { SYL2R }\end{array}$ & $\begin{array}{l}\text { GTGTCTCGCTGTGGTTGGTATATTTG } \\
\text { CTTCTGCCAATTGCACAAGTGC }\end{array}$ & 341 & 88.7 \\
\hline P. ultimum & $\begin{array}{l}\text { ULT1F } \\
\text { ULT4R }\end{array}$ & $\begin{array}{l}\text { GACACTGGAACGGGAGTCAGC } \\
\text { AAAGGACTCGACAGATTCTCGATC }\end{array}$ & 414 & 84.8 \\
\hline
\end{tabular}


were not isolated from soil, including $P$. attrantheridium and P. ultimum.

Similar results were obtained when soil extracts from the same locations described above were tested using a DNA macroarray. Five Pythium spp. were detected in the Cunningham Agronomy Farm sample and four species each in the Garfield and ARS Palouse Conservation Farm samples. $P$. heterothallicum and $P$. rostratifingens were detected at all three locations, whereas P. ultimum was found only in the Garfield sample. Hybridization signals specific for $P$. attrantheridium were detected in the Cunningham Agronomy Farm and ARS Palouse Conservation Farm samples. An oligonucleotide (par131), designed for part of the paroecandrum/irregulare complex, exhibited positive hybridization signals in all samples. However, because the oligonucleotide (par126) specific for $P$. paroecandrum did not exhibit any hybridization signal, it is highly probable that this species is not present. A P. torulosum oligonucleotide also weakly hybridized to the Cunningham Agronomy Farm sample.

\section{DISCUSSION}

Identification of Pythium spp. by classical methods of morphological features is time consuming and difficult. In this study, primers specific to nine pathogenic Pythium spp. commonly found in Washington were developed. These primers subsequently were used to develop an assay to identify and quantify species of Pythium from artificially and naturally infested soils, using a soil DNA extraction kit and real-time PCR.
Specific and sensitive detection using real-time PCR was achieved with all nine species of Pythium examined. The primer sets that were developed provided specific detection of the species for which they were designed and did not amplify nontarget DNA

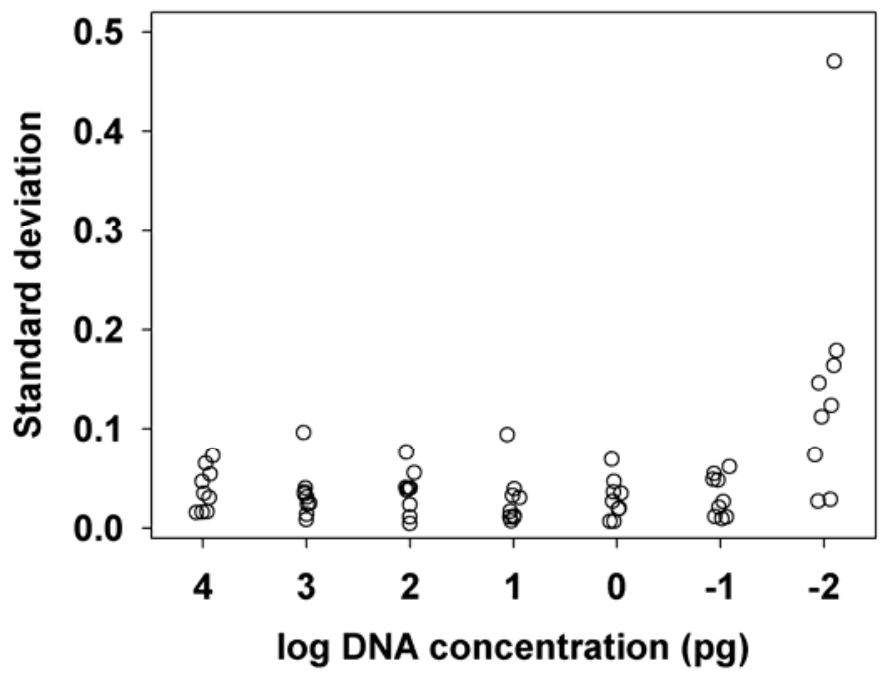

Fig. 2. Variability in quantification of DNA extracted from mycelia of cultured Pythium spp. using real-time polymerase chain reaction over a range of DNA concentrations (10 ng to $10 \mathrm{fg}$ ). Each point represents the standard deviation of three subsamples.

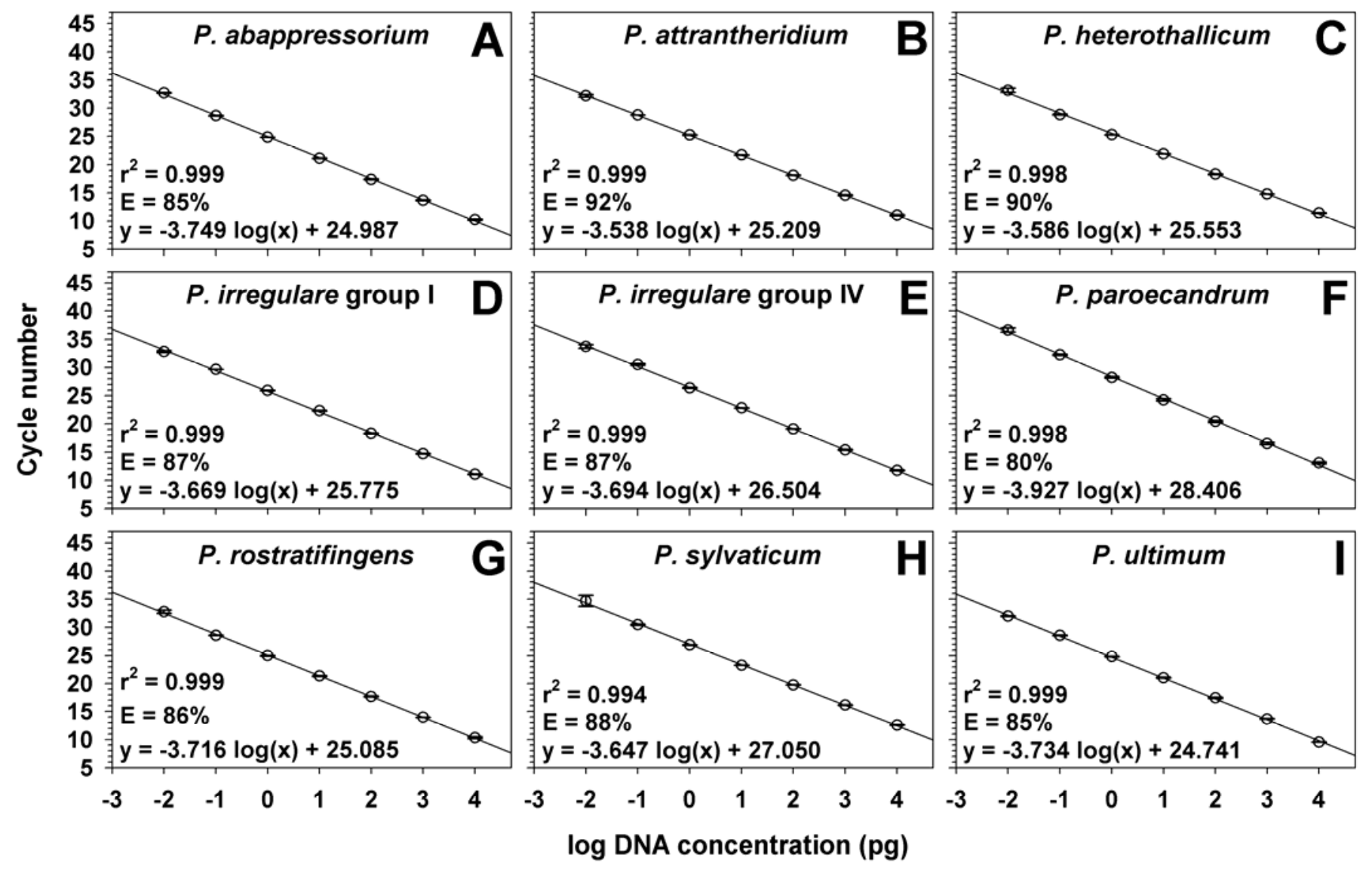

Fig. 1. Standard curves generated using real-time polymerase chain reaction for each Pythium species-specific primer set developed for identification and quantification. A range of DNA concentrations from $10 \mathrm{ng}$ to $10 \mathrm{fg}$ was used in generating the above graphs. Each DNA concentration was tested in triplicate. A, $P$. abappressorium primer set ABA1bF/ABA1R, B, $P$. attrantheridium primer set ATT3F/ATT2R, C, $P$. heterothallicum primer set HET4F/HET2R, D, $P$. irregulare group I primer set IRR3F/IRR3R, E, P. irregulare group IV primer set IIV2F/ABA1R, F, $P$. paroecandrum primer set PAR2F/PAR3R, G, $P$. rostratifingens primer set ROS4F/ROS3R, H, P. sylvaticum primer set SYL1F/SYL1R, and I, P. ultimum primer set ULT1F/ULT4R. The efficiency of each primer set was calculated using the formula: $\mathrm{E}=10^{(-1 / \text { slope })}-1$. 
of other Pythium spp. or other genera tested in this study. A primer set was designed previously for specific detection of $P$. ultimum and, when used in combination with traditional PCR, could detect $P$. ultimum from water-soaked lesions of cucumber, sugar beet, and Chinese cabbage (22). Wang et al. (50) recently developed a set of 20 PCR primers based on ITS1 sequence from 34 Pythium spp. However, they obtained specific detection only for $P$. acanthicum, $P$. rostratum, $P$. splendens, and $P$. sulcatum, with some primers amplifying more than one species. They developed a specific forward primer and used a universal primer (ITS2 or ITS4) as the reverse primer (50). In our study, both the forward and reverse primers were designed to be species specific, with a forward primer in either the ITS1 or ITS2 and a reverse primer in the ITS2. The use of two specific primers greatly increases the specificity of each primer set.

In developing standard curves for each primer set, detection was achieved at a fairly low template concentration of DNA (10 fg). In the development of an assay to detect Phytophthora capsici in pepper tissue, as little as $10 \mathrm{pg}$ of target DNA could be detected using SYBR Green in conjunction with a Bio-Rad iCycler (44). In the detection of Pyrenophora teres, a standard curve was generated using a range of concentrations from $2.5 \mathrm{ng}$ to $2.5 \mathrm{pg}$ (6). However, using a real-time nested PCR technique, Phytophthora ramorum could be detected at concentrations as low as $12 \mathrm{fg}$ (19). Quantification of DNA down to the low femtogram range also was reported for Colletotrichum coccodes when real-time PCR was performed using fluorescently labeled probes in combination with species-specific primers and an ABI Prism 7700 sequence detector (15). Based on amplification of samples from artificially infested soils and directly from the field soils, lower detection limits are likely possible. In testing field samples, as low as 2.6 and $4.5 \mathrm{fg}$ of $P$. ultimum DNA per reaction were detected from soils removed from a spring barley field in Garfield, and $1.4 \mathrm{fg}$ of $P$. rostratifingens DNA per reaction was detected from the Garfield fallow soil.

The standard curves were generated using a range of DNA concentrations from $10 \mathrm{ng}$ to $10 \mathrm{fg}$. At most DNA concentrations, the real-time PCR amplification was very reproducible, with average standard deviations of 0.033 for the concentration estimates. However, when only 10 fg of DNA were initially present in a reaction, the average standard deviation increased fourfold. Although quantification is still possible using a starting target DNA concentration of only $10 \mathrm{fg}$, the error increases at these low concentrations. Such increase in standard deviation is expected when the estimates are close to the limit of the range of the standards.

$P$. irregulare group I, $P$. irregulare group IV, and $P$. ultimum were chosen for amplification directly from soil because these three species previously were demonstrated to be the most virulent on wheat $(20,21)$. The isolates described as $P$. irregulare group IV in this article previously were designated $P$. debaryanum based on morphology and $97 \%$ sequence similarity $(20,42)$. How- ever, these same isolates share $100 \%$ sequence identity to isolates that were recovered from sugar beet in Japan and designated $P$. irregulare group IV (31). ITS sequence data evaluated by Lévesque and De Cock (25) also showed that $P$. irregulare group IV isolates occur in the same clade as the more common $P$. ir-

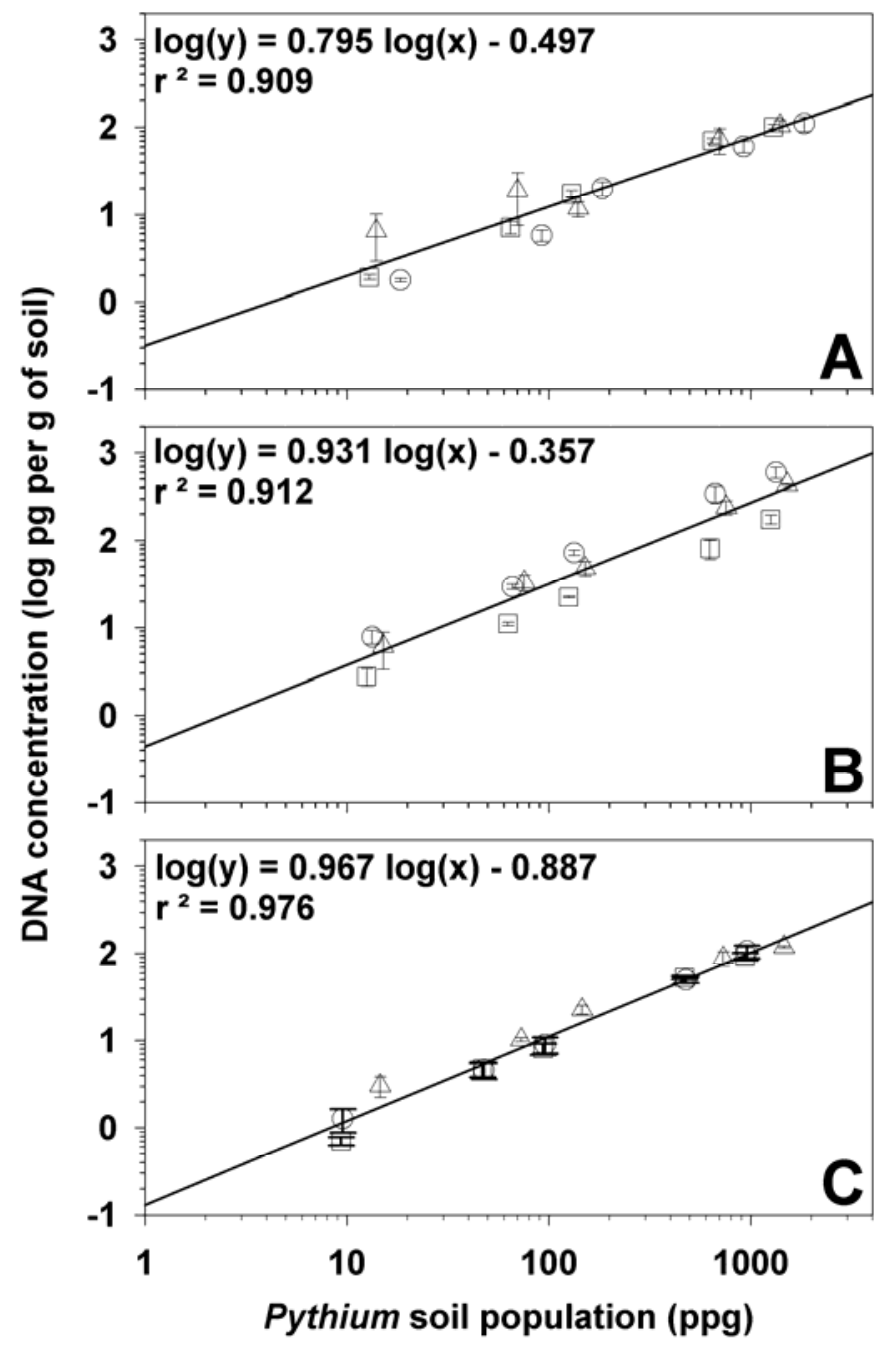

Fig. 3. Correlation of DNA recovered from soil samples with populations of Pythium spp. from the same soil. Pasteurized soils were artificially inoculated with A, P. irregulare group I isolates $110305(\Delta), 110306(\bigcirc)$, and 0900101 $(\square) ; \mathbf{B}$, P. irregulare group IV isolates $020117(\Delta), 020147(\bigcirc)$, and 020155 ( $\square)$; or C, $P$. ultimum isolates $030141(\Delta), 10118(\bigcirc)$, and $10145(\square)$. DNA was extracted from the soil using a MO BIO Laboratories soil DNA extraction kit and amplified by real-time polymerase chain reaction using a Roche LightCycler; ppg = propagules per gram.

TABLE 3. Summary of primer specificity using a collection of 77 isolates, representing nine Pythium spp. ${ }^{\mathrm{a}}$

\begin{tabular}{|c|c|c|c|c|c|}
\hline Species & Isolates & Isolates amplified & $\mathrm{C}_{\mathrm{t}}$ range (positive) & Nonspecific amplification ${ }^{b}$ & $\mathrm{C}_{\mathrm{t}}$ range (negative) \\
\hline Pythium abappressorium & 11 & 11 & $12.8-16.6$ & 0 & $35.1-43.7$ \\
\hline P. attrantheridium & 5 & 5 & $13.0-14.8$ & 0 & $32.0->46.0$ \\
\hline P. heterothallicum & 13 & 13 & $13.0-15.9$ & 0 & $29.5-36.7$ \\
\hline P. irregulare group I & 8 & 8 & $13.1-14.2$ & 0 & $31.3-34.3$ \\
\hline P. irregulare group IV & 11 & 11 & $13.1-15.0$ & 0 & $29.0-37.3$ \\
\hline P. paroecandrum & 3 & 3 & $13.8-15.3$ & 0 & $35.4->46.0$ \\
\hline P. rostratifingens & 11 & 11 & $12.1-14.7$ & 0 & $32.7->46.0$ \\
\hline P. sylvaticum & 2 & 2 & $13.1-13.6$ & 0 & $32.4->46.0$ \\
\hline P. ultimum & 13 & 13 & $11.5-16.1$ & 0 & $31.0-43.1$ \\
\hline
\end{tabular}

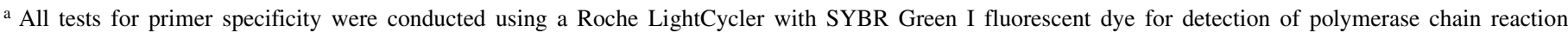
product. Positive amplifications were confirmed by examination of melting curves. For each sample, approximately 2 to 3 ng was used per reaction; $\mathrm{C}_{\mathrm{t}}=$ cycle threshold.

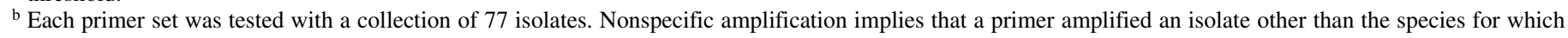
the primer was designed. 
regulare, but form a distinct cluster. The taxonomic status of the closely related cluster made by a CBS strain of $P$. debaryanum and some isolates of $P$. violae is unknown at this point. In a separate comparison of 68 isolates of $P$. irregulare based on ITS sequence, $P$. irregulare group IV was found to be more closely related to $P$. sylvaticum than to $P$. irregulare (18), which is consistent with the analysis of Lévesque and De Cock (25). P. irregulare group IV isolates in this study have numerous aplerotic oospores, with one or two monoclinous antheridia arising very close to the oogonium.

A method of DNA extraction was modified from a kit and realtime PCR amplification from soils was achieved. Using pasteurized soils that were artificially infested with Pythium spp., this technique was used to detect as few as $10 \mathrm{ppg}$. Similar sensitivity would be expected for the other primer sets developed in this study. In addition, greater sensitivity than observed under controlled conditions in this study is likely. In developing TaqManbased real-time PCR assay to detect Phytophthora medicaginis in alfalfa roots, resistant versus susceptible plants could be differentiated with an average of $50 \mathrm{pg}$ of DNA detected in resistant plants (47). Bates et al. (6) detected $<2 \%$ seed infection with Pyrenophora spp. using a similar assay that involved real-time PCR by means of a LightCycler and SYBR Green dye. Likewise, detection of as few as 1.5 conidia of Helminthosporium solani per gram of soil was demonstrated using TaqMan fluorogenic probes in combination with a 96-well format quantitative PCR (14).

The soil DNA extractions were highly reproducible; however, slight variability did exist between isolates. One possibility that was examined was that the copy number of nuclear rDNA differed between isolates. However, a simple test was conducted in which DNA from several isolates of $P$. ultimum was standardized to the same concentration. Hence, the number of genomes per $1 \mu \mathrm{l}$ of DNA should be approximately the same. A 10 -fold dilution series was constructed and each dilution was amplified using real-time PCR. The result was virtually identical $C_{t}$ values at all dilutions for each isolate, indicating very similar copy numbers per isolate.
The second and more likely possibility was that the population estimates made by dilution plating onto selective media were less precise than quantification of DNA. Previous research has demonstrated variability between PCR results and plating of samples onto selective medium. Kageyama et al. (22) found that P. ultimum could be detected in infected plant samples by PCR amplification, yet was undetectable when the same samples were placed onto a selective medium. Thus, use of selective media to quantify Pythium spp. directly from soil or any other substrate is less sensitive than PCR techniques and is only a rough estimate. Finally, Pythium spp. possess a number of different types of propagules, including sporangia, hyphae, and oospores. Sporangia can germinate readily and grow; whereas, with some species of Pythium, the oospores must undergo a period of dormancy before being capable of germinating $(3,28)$.

The population dynamics of Pythium spp. in soil is complex. In each of the soil samples examined in this study, between two and six pathogenic species were found per soil sample. Similarly, in a

TABLE 5. Percent amplification efficiency for soil extracts spiked with known amount of $\mathrm{DNA}^{\mathrm{a}}$

\begin{tabular}{|c|c|c|c|}
\hline \multirow[b]{2}{*}{ Soil $^{\mathrm{b}}$} & \multicolumn{3}{|c|}{ Efficiency $(\%)^{\mathrm{c}}$} \\
\hline & Pythium irregulare group I & P. irregulare group IV & P. ultimum \\
\hline Cunningham & 89.0 & 89.1 & 83.6 \\
\hline Garfield & 91.7 & 91.9 & 85.3 \\
\hline ARS-PCFS & 88.7 & 88.8 & 84.8 \\
\hline Control & 88.9 & 88.8 & 83.4 \\
\hline
\end{tabular}

${ }^{a}$ Soil extracts were spiked with 100 pg of Pythium spp. DNA and serial dilutions were made down to $10 \mathrm{fg}$. Values are the average of three replications.

b Soils were collected from the Cunningham Farm (Cunningham), Garfield, and the Agricultural Research Service Palouse Conservation Farm (ARSPCFS). Control = water only.

${ }^{c}$ Efficiency was calculated using the formula: $\mathrm{E}=10^{(1-\text { slope })}-1$. None of the differences in amplification efficiency were statistically significant using Fisher's least significant difference $(P=0.05)$.

TABLE 4. Summary of amplification of indigenous Pythium spp. from natural field soils using species-specific primers and real-time polymerase chain reaction (PCR)

\begin{tabular}{|c|c|c|c|c|c|}
\hline \multirow[b]{2}{*}{ Species } & \multicolumn{5}{|c|}{ DNA quantification from field soils (fg/g of soil) ${ }^{\mathrm{a}}$} \\
\hline & Cunningham WW & Cunningham fallow & Garfield SB & Garfield fallow & ARS-PCFS SW \\
\hline \multicolumn{6}{|l|}{ Wet soils } \\
\hline Pythium abappressorium & 2,735 & 6,065 & 680 & - & - \\
\hline P. heterothallicum & 6,000 & 7,290 & 1,565 & - & $(440)$ \\
\hline P. irregulare group I & - & - & 7,980 & - & - \\
\hline P. irregulare group $\mathrm{IV}^{\mathrm{b}}$ & - & $?$ & $?$ & _- & $?$ \\
\hline P. sylvaticum & - & - & - & _- & - \\
\hline P. ultimum & - & - & $(130)$ & - & - \\
\hline Total $(\mathrm{ppg})^{\mathrm{c}}$ & 1,210 & 1,130 & 1,300 & 570 & 2,070 \\
\hline \multicolumn{6}{|l|}{ Dry soils } \\
\hline P. abappressorium & 2,775 & 2,505 & 580 & $(490)$ & - \\
\hline P. attrantheridium & - & - & 4,445 & - & 3,045 \\
\hline P. heterothallicum & 3,705 & 4,730 & 3,740 & - & 550 \\
\hline P. ultimum & - & - & $(225)$ & - & - \\
\hline Total $(\mathrm{ppg})^{\mathrm{c}}$ & 410 & 650 & 1,280 & 200 & 960 \\
\hline
\end{tabular}


recent survey of Pythium spp. from eastern Washington, up to six species were recovered from a single soil sample (42). Quantification and identification also followed closely with the previous history at each location. The highest recovery in both plate counts on selective media and from quantitative PCR was from the spring barley field in Garfield. Lower populations were detected in the cropped soils at the Cunningham Agronomy Farm and the ARS Palouse Conservation Farm. The lowest population was from the second field at Garfield that was maintained in mechanical summer fallow over the 2004 growing season. Populations recovered from the fallow soil at the Cunningham Agronomy Farm were very similar to those from the cropped soil. The fallow soil was a patch of land that was being maintained by chemical fallow within a wheat field. However, later in the growing season, these patches became overgrown in weeds. In addition, the field was harvested prior to sampling from the fallow area and sampling was preceded by several days of rainfall. In controlled growth-chamber studies, Cook et al. (12) demonstrated that the addition of wheat chaff to a soil could substantially increase the population of Pythium spp. within 4 days. Thus, the combination of wheat chaff spread over the fallow areas and rain after harvest may have contributed to similar populations between fallow and cropped soils at the Cunningham Agronomy Farm.

The morphological identification of Pythium spp. from field soils examined in this study revealed similar information about population dynamics when compared with the real-time PCR data. $P$. rostratifingens, $P$. irregulare group $\mathrm{IV}$, and $P$. abappressorium represented the most commonly isolated species based on morphological data and higher quantities of DNA were amplified for these same species using real-time PCR, although specific quantities of DNA could not be determined for $P$. irregulare group IV. The primer set that was used for $P$. irregulare group IV was an earlier version that performed unacceptably in soils, resulting in high nontarget background amplification. A sample was not available to be retested with the improved IIV7F/ABA1R primer set. Likewise, $P$. paroecandrum and $P$. sylvaticum were not recovered from grass blades and were not observed using real-time PCR. However, several species that were detected by real-time PCR were not isolated from the soil. In the Garfield soil cropped to spring barley, similar levels of amplification with real-time PCR were detected for $P$. attrantheridium, $P$. heterothallicum, $P$. irregulare, and $P$. rostratifingens; however, only $P$. irregulare and $P$. rostratifingens were recovered from soil by baiting. Many more isolates likely would need to be examined to recover all of the species that were identified by real-time PCR, and the proportion of species recovered likely would differ from that observed with real-time PCR due to experimental variability in the recovery of each species by baiting.

Similar results also were observed using the DNA macroarray. As with the results from real-time PCR, P. heterothallicum and $P$. rostratifingens were detected from all three field locations, P. ultimum was found only in Garfield soil, and P. paroecandrum and $P$. sylvaticum were not present in any of the samples. Similar results also were observed for $P$. attrantheridium, although the DNA macroarray detected this species at the ARS Palouse Conservation Farm but not at Garfield, contrary to the results of realtime PCR. $P$. abappressorium and $P$. irregulare group IV were not detected by DNA macroarray. However, BLAST analysis of the paroecandrum group oligonucleotide (par131) against 500 Pythium entries in GenBank revealed a perfect match to sequences of $P$. abappressorium, a species with no specific oligonucleotide on the array. $P$. irregulare group IV also does not yet have a specific oligonucleotide on the array; therefore, no supportive data is available for this species.

A useful feature of real-time PCR as performed using the Roche LightCycler is the ability to examine the melting curves of the products formed to check the purity and confirm the identity of the product. Each product formed by PCR amplification will have a distinct melting curve based on the length and base composition of the product. In field samples, a very small amount of background amplification was present in negative samples using several of the primer sets. However, by examining the melting curve and peaks, positive samples easily can be distinguished from nontarget amplification. In the case of $P$. irregulare group IV, specific amplification occurred in three of the soils. However, some of the amplification was due to nontarget amplification. By examining the melting profile, the presence or absence of $P$. irregulare group IV could still be discerned in the three soils.

Despite examining only a few field samples, similarities to previous work were evident. Paulitz and Adams (42) found six species of Pythium to occur at frequencies above $25 \%$. In order from highest recovery to lowest, they were $P$. abappressorium, $P$. rostratifingens (aff. $P$. rostratum), $P$. irregulare group IV (aff. $P$. debaryanum), $P$. heterothallicum, and $P$. ultimum. The $P$. rostratum referred to by Paulitz and Adams (42) recently was classified as $P$. rostratifingens based on ITS sequence and various morphological factors, including the absence of catenulate oogonia and differences in oogonia and sporangia size (16). In this study, the highest frequency of specific amplification using real-time PCR was with $P$. heterothallicum and $P$. rostratifingens primers sets, with both species being identified from four of the five soils. $P$. abappressorium and $P$. irregulare group IV also were observed

TABLE 6. Pythium spp. isolated from field soils that were identified by morphological features and confirmed by sequencing of representative isolates and compared to a database (25)

\begin{tabular}{|c|c|c|c|c|c|}
\hline \multirow[b]{2}{*}{ Species } & \multicolumn{5}{|c|}{ Number of isolates per field soil sample ${ }^{\mathrm{a}}$} \\
\hline & Cunningham WW & Cunningham fallow & Garfield SB & Garfield fallow & ARS-PCFS SW \\
\hline Pythium abappressorium & 5 & - & - & 1 & 2 \\
\hline$P$. attrantheridium & - & - & - & - & - \\
\hline P. heterothallicum & - & 3 & - & 1 & - \\
\hline P. irregulare group I & - & - & 1 & - & - \\
\hline P. irregulare group IV & 1 & 3 & 4 & - & 4 \\
\hline P. paroecandrum & - & - & - & - & - \\
\hline P. pachycaule & 2 & - & 2 & 1 & - \\
\hline$P$. rostratifingens & 11 & - & 6 & - & 14 \\
\hline P. sylvaticum & - & - & - & - & - \\
\hline P. ultimum & - & - & - & - & - \\
\hline Unidentified & - & - & 2 & 1 & - \\
\hline Total & 19 & 6 & 15 & 4 & 20 \\
\hline
\end{tabular}

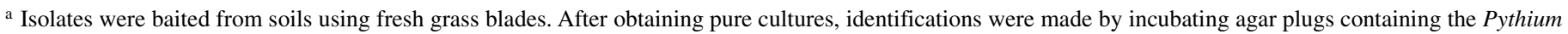
spp. in pond water with sterilized, dried grass blades and examining the sexual and asexual features of each isolate. Samples with a dash (-) indicate the particular species was not among the isolates examined. Soils were collected from the Cunningham Farm (Cunningham), Garfield, and the Agricultural Research Service Palouse Conservation Farm (ARS-PCFS). WW = winter wheat, SB = spring barley, and SW = spring wheat.

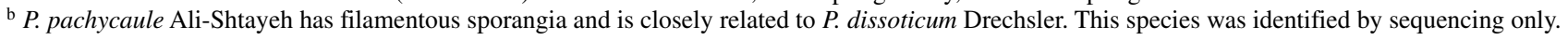


at a high frequency in three of five samples. P. irregulare and $P$. ultimum were identified from one of five samples, which also closely follows the observations of Paulitz and Adams (42). Thus, the real-time PCR technique appears to produce results similar to those obtained with a large-scale survey.

Traditional methods of enumerating and identifying Pythium spp. rely on the use of selective media and microscopic identification of reproductive features of each isolate. These processes are laborious, requiring up to 8 to 14 days for species identification. This same process can be accomplished in only a few hours using soil DNA extraction techniques and real-time PCR. In addition, real-time PCR is a very sensitive technique, capable of detecting low population densities of certain Pythium spp. that might be overlooked by traditional methods of screening.

In this study, primers were developed for the nine most commonly isolated pathogenic Pythium spp. in Washington. However, over 120 species of Pythium have been described (2). Because a comprehensive collection of Pythium spp. was not screened, some nonspecific amplification might occur with species of Pythium not commonly found in eastern Washington. Both primers for each set, with the exception of the reverse primer for $P$. abappressorium and $P$. irregulare group IV, were designed to specifically amplify only one species. Because both primers were designed to be specific, the likelihood of both primers binding to sequences of nontarget species is reduced. This is supported by findings from the in silico tests. In the pairings where $\Delta \mathrm{G}$ values were low, only one primer of the pair was predicted to form a hybrid. Therefore, the potential for double-stranded, nonspecific amplification was considered to be nil. The exception was the pairing of PAR3R and SYL1F, which was predicted to amplify $P$. sylvaticum ITS DNA. Thus, there would be a limitation in adopting these primer sets for multiplexing in future assays. Further testing of these primers with local species also may be necessary if this procedure were adopted in other areas.

The method for identification and quantification outlined in this article will serve as a useful tool for study of Pythium spp. The technique is very sensitive and fast compared with traditional methods of dilution plating and microscopic observation of morphological features. There are numerous applications for this new technique that will greatly improve our understanding of Pythium spp. and the diseases that they cause. The use of this technique will be very beneficial for studying the epidemiology of this pathogen in soils, including how geography, temperature, moisture, and cropping systems affect the species composition of this pathogen. It also will prove useful from a disease management perspective for the evaluation of various control measures, including fungicide sensitivity, quantitative host resistance, and various cultural management strategies.

\section{LITERATURE CITED}

1. Ali-Shtayeh, M. S., Lim-Ho, C. L., and Dick, M. W. 1986. An improved method and medium for quantitative estimates of populations of Pythium species from soil. Trans. Br. Mycol. Soc. 86:39-47.

2. Allain-Boule, N., Tweddell, R., Mazzola, M., Bélanger, R., and Lévesque, C. A. 2004. Pythium attrantheridium sp. nov.: Taxonomy and comparison with related species. Mycol. Res. 108:795-805.

3. Ayers, W. A., and Lumsden, R. D. 1975. Factors affecting production and germination of oospores of three Pythium species. Phytopathology 65:1094-1100.

4. Bailey, A. M., Mitchell, D. J., Manjunath, K. L., Nolasco, G., and Niblett, C. L. 2002. Identification to the species level of the plant pathogens Phytophthora and Pythium by using unique sequences of the ITS1 region of ribosomal DNA as capture probes for PCR ELISA. FEMS Microbiol. Lett. 207:153-158.

5. Bakkeren, G., Kronstad, J. W., and Lévesque, C. A. 2000. Comparison of AFLP fingerprints and ITS sequences as phylogenetic markers in Ustilaginomycetes. Mycologia 92:510-521.

6. Bates, J. A., Taylor, E. J. A., Kenyon, D. M., and Thomas, J. E. 2001. The application of real-time PCR to the identification, detection and quantification of Pyrenophora species in barley seeds. Mol. Plant Pathol. 2:49-57.
7. Böhm, J., Hahn, A., Schubert, R., Bahnweg, G., Adler, N., Nechwatal, J., Oehlmann, R., and Obwald, W. 1999. Real-time quantitative PCR: DNA determination in isolated spores of the mycorrhizal fungus Glomus mosseae and monitoring of Phytophthora infestans and Phytophthora citricola in their respective host plants. J. Phytopathol. 147:409-416.

8. Chamswarng, C., and Cook, R. J. 1985. Identification and comparative pathogenicity of Pythium species from wheat roots and wheat-field soils in the Pacific Northwest. Phytopathology 75:821-827.

9. Chen, W. 1992. Restriction fragment length polymorphisms in enzymatically amplified ribosomal DNAs of three heterothallic Pythium species. Phytopathology 82:1467-1472.

10. Chen, W., Hoy, J. W., and Schneider, R. W. 1992. Species-specific polymorphisms in transcribed ribosomal DNA of five Pythium species. Exp. Mycol. 16:22-34.

11. Conway, K. E. 1985. Selective medium for isolation of Pythium spp. from soil. Plant Dis. 69:393-395.

12. Cook, R. J., Chamswarng, C., and Tang, W.-H. 1990. Influence of wheat chaff and tillage on Pythium populations in soil and Pythium damage to wheat. Soil Biol. Biochem. 22:939-947.

13. Cook, R. J., and Veseth, R. J. 1991. Wheat Health Management. The American Phytopathological Society, St. Paul, MN.

14. Cullen, D. W., Lees, A. K., Toth, I. K., and Duncan, J. M. 2001. Conventional PCR and real-time quantification PCR detection of Helminthosporium solani in soil and on potato tubers. Eur. J. Plant Pathol. 107:387398.

15. Cullen, D. W., Lees, A. K., Toth, I. K., and Duncan, J. M. 2002. Detection of Colletotrichum coccodes from soil and potato tubers by conventional and quantitative real-time PCR. Plant Pathol. 51:281-292.

16. de Cock, A. W. A. M., and Lévesque, C. A. 2004. New species of Pythium and Phytophthora. Stud. Mycol. 50:481-487.

17. Filion, M., St-Arnaud, M., and Jabaji-Hare, S. H. 2002. Direct quantification of fungal DNA from soil substrate using real-time PCR. J. Microbiol. Methods 53:67-76.

18. Garzón, C. D., Geiser, D. M., and Moorman, G. W. 2005. Amplified fragment length polymorphism analysis and internal transcribed spacer and coxII sequences reveal a species boundary within Pythium irregulare. Phytopathology 95:1489-1498.

19. Hayden, K. J., Rizzo, D., Tse, J., and Garbelotto, M. 2004. Detection and quantification of Phytophthora ramorum from California forests using a real-time polymerase chain reaction assay. Phytopathology 94:1075-1083.

20. Higginbotham, R. W., Paulitz, T. C., and Kidwell, K. K. 2004. Virulence of Pythium species isolated from wheat fields in eastern Washington. Plant Dis. 88:1021-1026.

21. Ingram, D. M., and Cook, R. J. 1990. Pathogenicity of four Pythium species to wheat, barley, peas and lentils. Plant Pathol. 39:110-117.

22. Kageyama, K., Ohyama, A., and Hyakumachi, M. 1997. Detection of Pythium ultimum using polymerase chain reaction with species-specific primers. Plant Dis. 81:1155-1160.

23. Klassen, G. R., Balcerzak, M., and de Cock, A. W. A. M. 1996. 5S ribosomal RNA gene spacers as species-specific probes for eight species of Pythium. Phytopathology 86:581-587.

24. Lees, A. K., Cullen, D. W., Sullivan, L., and Nicolson, M. J. 2002. Development of conventional and quantitative real-time PCR assays for the detection and identification of Rhizoctonia solani AG-3 in potato and soil. Plant Pathol. 51:293-302.

25. Lévesque, C. A., and de Cock, W. A. M. 2004. Molecular phylogeny and taxonomy of the genus Pythium. Mycol. Res. 108:1363-1383.

26. Lévesque, C. A., Harlton, C. E., and de Cock, A. W. A. M. 1998. Identification of some oomycetes by reverse dot blot hybridization. Phytopathology 88:213-222.

27. Lévesque, C. A., Vrain, T. C., and De Boer, S. H. 1994. Development of a species-specific probe for Pythium ultimum using amplified ribosomal DNA. Phytopathology 84:474-478.

28. Lumsden, R. D., and Ayers, W. A. 1975. Influence of soil environment on the germinability of constitutively dormant oospores of Pythium ultimum. Phytopathology 65:1101-1107.

29. Martin, F. N. 2000. Phylogenetic relationships among some Pythium species inferred from sequence analysis of the mitochondrially encoded cytochrome oxidase II gene. Mycologia 92:711-727.

30. Matsumoto, C., Kageyama, K., Suga, H., and Hyakumachi, M. 1999. Phylogenetic relationships of Pythium species based on ITS and 5.8S sequences of the ribosomal DNA. Mycoscience 40:321-331.

31. Matsumoto, C., Kageyama, K., Suga, H., and Hyakumachi, M. 2000. Intraspecific DNA polymorphisms of Pythium irregulare. Mycol. Res. 104:1333-1341.

32. Mazzola, M., Andrews, P. K., Reganold, J. P., and Lévesque, C. A. 2002. Frequency, virulence, and metalaxyl sensitivity of Pythium spp. isolated from apple roots under conventional and organic production systems. Plant Dis. 86:669-675. 
33. Mircetich, S. M., and Kraft, J. M. 1973. Efficiency of various selective media in determining Pythium population in soil. Mycopathol. Mycol. Appl. 50:151-161.

34. Paul, B. 1999. Pythium ornacarpum: A new species with ornamented oogonia isolated from soil in France. FEMS Microbiol. Lett. 180:337-344.

35. Paul, B. 2001. ITS region of the rDNA of Pythium longandrum, a new species; Its taxonomy and its comparison with related species. FEMS Microbiol. Lett. 202:239-242.

36. Paul, B. 2002. ITS1 region of the rDNA of Pythium proliferatum, a new species: Its taxonomy and its comparison with related species. FEMS Microbiol. Lett. 206:191-196.

37. Paul, B. 2002. ITS region of Pythium canariense sp. nov., its morphology and its interaction with Botrytis cinerea. FEMS Microbiol. Lett. 208:135141.

38. Paul, B. 2002. Pythium terrestris, a new species isolated from France, its ITS region, taxonomy and its comparison with related species. FEMS Microbiol. Lett. 212:255-260.

39. Paul, B. 2002. Pythium segnitium sp. nov., isolated from the Canary Islands-its taxonomy, ITS region of rDNA, and comparison with related species. FEMS Microbiol. Lett. 217:207-212.

40. Paul, B. 2003. Pythium carbonicum, a new species isolated from a spoil heap in northern France, the ITS region, taxonomy and comparison with related species. FEMS Microbiol. Lett. 219:267-274.

41. Paul, B. 2003. Pythium glomeratum, a new species isolated from agricultural soil taken in north-eastern France, its ITS region and its comparison with related species. FEMS Microbiol. Lett. 225:47-52.

42. Paulitz, T. C., and Adams, K. 2003. Composition and distribution of Pythium communities in wheat fields in eastern Washington state. Phytopathology 93:867-873
43. Paulitz, T. C., Adams, K., and Mazzola, M. 2003. Pythium abappressorium-a new species from eastern Washington. Mycologia 95:80-86.

44. Silvar, C., Díaz, J., and Merino, F. 2005. Real-time polymerase chain reaction quantification of Phytophthora capsici in different pepper genotypes. Phytopathology 95:1423-1429.

45. Tambong, J. T., de Cock, A. W. A. M., Tinker, N. A., and Lévesque, C. A. 2006. Oligonucleotide array for identification and detection of Pythium species. Appl. Environ. Microbiol. 72:2691-2706.

46. Taylor, E. J. A., Stevens, E. A., Bates, J. A., Morreale, G., Lee, D., Kenyon, D. M., and Thomas, J. E. 2001. Rapid-cycle PCR detection of Pyrenophora graminea from barley seed. Plant Pathol. 50:347-355.

47. Vandemark, G. J., and Barker, B. M. 2003. Quantifying Phytophthora medicaginis in susceptible and resistant alfalfa with a real-time fluorescent PCR assay. J. Phytopathol. 151:577-583.

48. Van der Plaats-Niterink, A. J. 1981. Monograph of the genus Pythium. No. 21, Studies in Mycology. Centraalbureau Voor Schimmelcultures, Baarn, The Netherlands.

49. Wang, P. H., and Chang, C. W. 2003. Detection of the low-germinationrate resting oospores of Pythium myriotylum from soil by PCR. Lett. Appl. Microbiol. 36:157-161.

50. Wang, P. H., Wang, Y. T., and White, J. G. 2003. Species-specific PCR primers for Pythium developed from ribosomal ITS1 region. Lett. Appl. Microbiol. 37:127-132.

51. Wang, P. H., and White, J. G. 1997. Molecular characterization of Pythium species based on RFLP analysis of the internal transcribed spacer region of ribosomal DNA. Physiol. Mol. Plant Pathol. 51:129-143.

52. Whittwer, C. T., Herrmann, M. G., Moss, A. A., and Rasmussen, R. P. 1997. Continuous fluorescence monitoring of rapid cycle DNA amplification. BioTechniques 22:130-138. 